\title{
New information on the distribution, breeding and conservation of Double-banded Greytail Xenerpestes minlosi (Furnariidae) in Ecuador
}

\author{
Alejandro Solano-Ugalde ${ }^{1,2,3, *}$, Lelis Navarrete ${ }^{2,3}$, Juan F. Freile ${ }^{2}$ \\ ${ }^{1}$ Fundación Imaymana, Paltapamba 476 San Pedro del Valle, Nayón, Quito, Ecuador. \\ ${ }^{2}$ Comité Ecuatoriano de Registros Ornitológicos (CERO), Pasaje El Moro E4-216 y Norberto Salazar, Tumbaco, Ecuador. \\ ${ }^{3}$ Neblina Forest Natural History and Birding Tours, Isla Floreana e8-129, Quito, Ecuador. \\ * Autor para correspondencia / Corresponding author, e-mail: jhalezion@gmail.com
}

Editado por/Edited by: Diego F. Cisneros-Heredia

Recibido/Received: 12/05/2017. Aceptado/Accepted: 14/08/2017.

Publicado en línea/Published online: 11/12/2017.

DOI: http://dx.doi.org/10.18272/reo.v0i1.890

Nueva información sobre la distribución, reproducción y conservación del Colagrís Alibandeado Xenerpestes minlosi (Furnariidae) en Ecuador

\section{Resumen}

Existen pocos registros del Colagrís Alibandeado Xenerpestes minlosi en Ecuador, la mayoría en la provincia de Pichincha. En esta nota presentamos nuevos registros de distribución y los primeros datos de reproducción en Ecuador. La especie no se considera globalmente amenazada, pero la elevada tasa actual de pérdida de bosques en su pequeña área de distribución en Ecuador sugiere que su estado de conservación en este país es más crítico de lo que se considera.

Palabras clave: Amenazas, Chocó, registros, reproducción, Xenerpestes minlosi.

\begin{abstract}
There are few records of the Double-banded Greytail Xenerpestes minlosi in Ecuador, mostly from Pichincha province. Here we report new distributional records and the first breeding data for Ecuador. The species is not ranked as globally threatened, but current rates of forest loss along its narrow distributional range in Ecuador suggest that its conservation status in this country is more critical than currently expected.
\end{abstract}

Keywords: breeding, Chocó, records, threats, Xenerpestes minlosi.

The Double-banded Greytail Xenerpestes minlosi was known, until recently, from sparse records in the lowlands of eastern Panama, the Pacific coast of Colombia (south to the lower Río San Juan), and along the northern base of the Andes in Colombia to the mid-Magdalena Valley (Hilty \& Brown, 1986). The species was recorded for the first time in Ecuador as recently as 1995 near Pedro Vicente Maldonado, Pichincha province (Ridgely \& Greenfield, 2001). It occurs up to $900 \mathrm{~m}$ a.s.l. in Colombia (Hilty \& Brown, 1986), but it does not range above $600 \mathrm{~m}$ in Ecuador (400-500 m in Ridgely \& Greenfield, 2001; below $600 \mathrm{~m}$ in McMullan \& Navarrete, 2013).

The species is nearly endemic to the Chocó biogeographic region (Stattersfield et al., 1998). Globally, it is not considered at risk (BirdLife International, 2016), but it was ranked as Vulnerable in Ecuador (Guerrero, 2002), being rare and local in the canopy of tropical and foothill primary forests and adjacent secondary woodland in the Pacific lowlands and western base of the Andes. In Ecuador, it was known primarily from two localities: Simón Bolívar Road, near Pedro Vicente Maldonado, province of Pichincha; and Salto del Tigre, southwest 
province of Imbabura (Ridgely \& Greenfield, 2001). With records being scarce, new information on its distribution, natural history, and conservation is desirable.

In this note, we present novel records from the provinces of Esmeraldas and Pichincha and provide the first observations of breeding in the country. We also discuss its conservation status in Ecuador and present a map of potential distribution and currently known localities (Fig. 1). This map was prepared using the software Maxent (Phillips et al., 2006), using 19 bioclimatic Worldclim variables (http://worldclim.org/bioclim) and all known distribution records of the species; areas with more than $68 \%$ of occurrence probability were selected for the final model (Fig. 1).

Our first record was obtained on 20 September 2007 when LN found an active nest at Tundaloma Lodge $(1.18305,-78.755,35 \mathrm{~m})$, roughly $17 \mathrm{~km}$ east of San Lorenzo town, province of Esmeraldas. Three birds were observed feeding chicks, actively moving in and out the nest while a large mixed species flock was crossing the nest tree area. The birds were acrobatically clinging upside down from big leaves looking for small prey, spending more time searching the undersides of foliage. The buffy-whitish underparts, grey upperparts, long white supercilium, whitish wingbars, and longish tail were key features for visual identification (Ridgely \& Greenfield, 2001). The nest was located c. $30 \mathrm{~m}$ above the ground on the terminal branches of a large tree at the gardens close to the lodge's main deck. It was bulky and globular, and was attached to a fork on a horizontal and partially hidden thin branch. The dimensions were visually estimated to be $30 \mathrm{~cm}$ tall by $20 \mathrm{~cm}$ wide. The nest was made of thin and longish dry sticks, with a lateral entrance facing downwards.

Two additional individuals were observed by AS-U acrobatically following a mixed sub-canopy flock on 13 March 2008 at Tundaloma Lodge. Further observations from the lodge deck overlooking the canopy of forest edge, revealed that one of this pair was feeding a third individual. The latter bird had similar plumage pattern but lacked the well-defined wing bars and showed conspicuous yellowish gapes, suggesting it was a juvenile. Another pair was heard and seen by AS-U on 12 January 2008 at the Quinto Piso Private Reserve (1.095, $78.852,28 \mathrm{~m}$ ), c. $6.5 \mathrm{~km} \mathrm{~S}$ from Yalare town, on the way to Concepción, province of Esmeraldas.

A new record in the province of Pichincha involves a single bird briefly observed by JFF and AS-U following a mixed species flock in forest edge and gallery forest along a small stream at Mashpi $(0.1588,-78.902,525 \mathrm{~m}$ a.s.1.), $30 \mathrm{~km}$ north-west of San Miguel de Los Bancos, on 4 January 2014. It moved acrobatically among the outer foliage of terminal twigs in dense bushes and trees, coming in and out of foliage as if actively searching prey. It kept going with the passing flock and soon went out of sight.

Our records fill an important gap in the distribution of the species in Ecuador and represent the first detailed records from the province of Esmeraldas (Ridgely \& Greenfield, 2006). The Esmeraldas records presented herein are at a lower elevation compared to previous published records in the country (Ridgely \& Greenfield, 2001; McMullan \& Navarrete 2013). In Panama and Colombia the species is also known from low elevations (Hilty \& Brown, 1986; Ridgely \& Gwynne, 1989).

To our knowledge the observations presented herein, together with a pair seeing carrying nesting material on 23 May 2006 at Silanche Bird Sanctuary, province of Pichincha (R. Alhman, in litt. 2007), represent the first observations of breeding of the species in Ecuador, and confirms previous remarks about its nest (Remsen, 2016). Breeding in the province of Esmeraldas might occur during the onset of the wet season (late September), which broadly coincides with the breeding periods of a large number of species in the Chocó region (Greeney \& Nunnery, 2006; Solano-Ugalde et al., 2007). Additional breeding data is scarce, but a juvenile was being fed in April in Panama, during the onset of the rainy season (Durán-Quesada et al., 2012).

We report the first observation of nest helpers in Xenerpestes (Parker \& Parker, 1980; Remsen, 2016) from our observation of three birds visiting the nest and feeding chicks at Tundaloma. Nest helpers, defined as additional individuals attending nestlings and feeding young, are a major rarity in the Furnariidae family as far as known (Remsen, 2003; 2016). It has been reported for the enigmatic Pink-legged Graveteiro Acrobatornis fonsecai (Whitney et al., 1996), which is closely related to Xenerpestes (Derryberry et al., 2011). The Orangefronted Plushcrown Metopothrix aurantiaca, grouped in the same clade as Xenerpestes and Acrobatornis, has individuals of previous offspring participating in family nest attendance (Remsen, 2003). A species grouped in a different clade, the Rufous-fronted Thornbill Phacellodomus rufifrons, breeds in pairs accompanied by additional individuals, presumably young birds of previous offspring, which help in nest building, 
maintenance and defence but apparently not -or very occasionally only- in chick rearing (Thomas, 1983; Remsen, 2003). Likewise, in the Caatinga Cachalote Pseudoseisura cristata up to four adult birds feed nestlings, while young birds of previous offspring also help in nest building (Remsen, 2003). Nest architecture was similar to the Equatorial Greytail X. singularis, for which nesting data is also scarce (Remsen, 2003). As discussed by Zyskowski \& Prum (1999), nest architecture is phylogenetically informative in the Furnariidae. Even though it seems plausible that other aspects of their breeding biology are also informative in systematics, like the presence of nest helpers; they might actually be ecologically driven and not phylogenetically related.

In Figure 1 we present the potential distribution and known localities of Xenerpestes minlosi in Ecuador, showing a large gap in knowledge between northern Esmeraldas and Pichincha. The occurrence of X. minlosi in the Cotacachi Cayapas Ecological Reserve (243,638 ha), the only large protected area within its Ecuadorian range, remains to be determined (Guerrero, 2002). To our knowledge, the species has only been reported from three privately owned protected areas in the country: Tundaloma (65 ha), Silanche (81 ha), and Canandé (c. 2,000 ha), and one communal reserve (Playa de Oro; c. 4,400 ha), where the status of the species is not well known. There is only one unconfirmed sighting in a 9-years study period in Playa de Oro community, neighbouring Cotacachi Cayapas (Jahn, 2011). This suggests that the species is an extremely rare resident in Playa de Oro (Jahn, 2011), but it is also conceivable that the species is an infrequent visitor to the region. A single additional record from Playa de Oro area was obtained in October 2014 (Gelis, 2014). The species might also occur in the Awá Ethnic Reserve (c. 120,000 ha) and Cayapas Mataje Ecological Reserve (49,350 ha), as suggested by a single record by Jahn (2011) at 80-150 m a.s.l. from Awacachi Biological Corridor, 25 $\mathrm{km}$ NE of Playa de Oro and c. $10 \mathrm{~km}$ E of Tundaloma. Additionally, our Mashpi record is located within a municipal protected area, under a management category of conservation and sustainable use area.

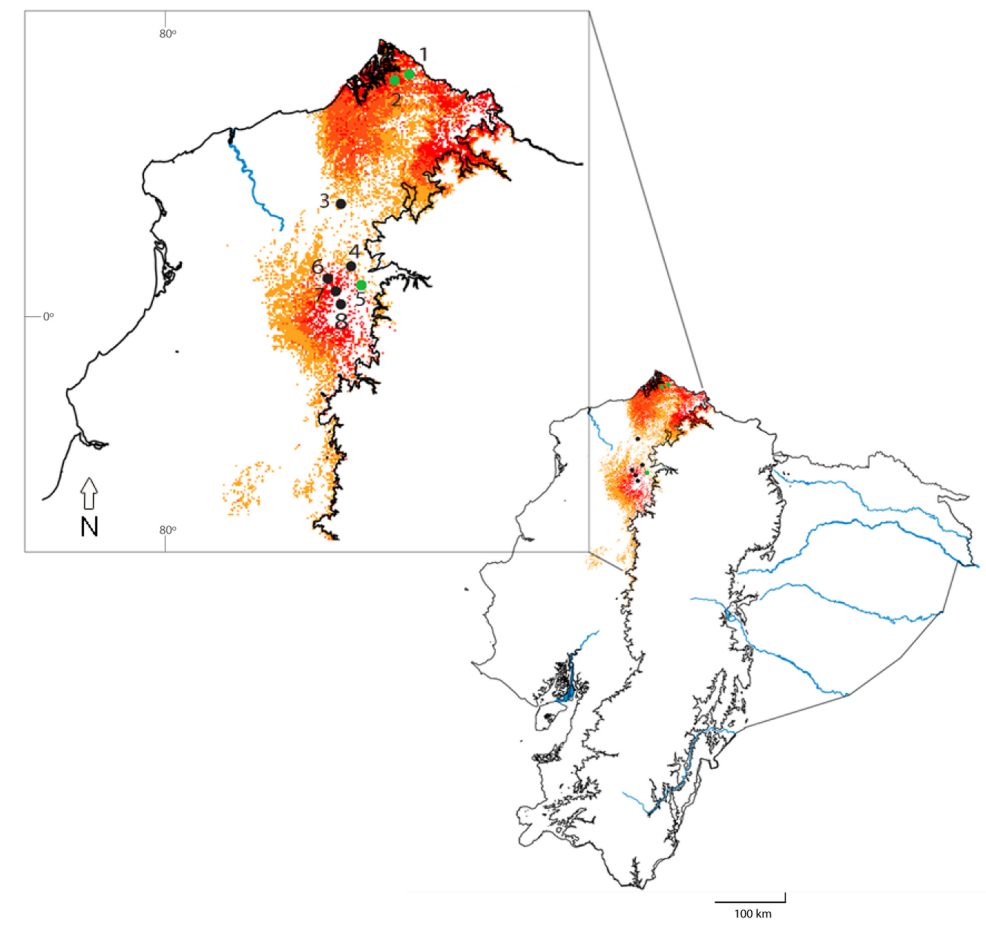

Figure 1: Potential distribution and currently known localities of Double-banded Greytail Xenerpestes minlosi in Ecuador. Redder areas show higher occurrence probability: dark red (>91\% probability); reddish (79-91\%); ochre (68$78 \%)$. Deforested areas are not segregated. Green dots represent new localities presented in this note. Black contour line at 1,000 m a.s.l. Localities: 1) Tundaloma; 2) Quinto Piso; 3) Canandé; 4) Salto del Tigre; 5) Mashpi; 6) Simón Bolívar Road; 7) Silanche; 8) west of Pedro Vicente Maldonado.

Tundaloma and Silanche are small and might only hold minor populations. The situation in previously known localities (Simón Bolívar Road and Salto del Tigre) is more critical due to extensive deforestation and forest 
clearing for cattle ranching, oil palm, and palm-heart monoculture. Populations in these areas are likely declining and will continue to do so at a fast rate. Even though it apparently was never numerous in the Silanche area, records were more frequent in the late 1990s and early 2000s (pers. obs.), whereas recent sightings are becoming scarcer despite being visited by observers on a regular almost monthly basis. Our two localities in Esmeraldas also face a critical conservation status. At Tundaloma, we have witnessed the decline or disappearance of several forest species over the last decade. There is little connectivity between this small reserve and more extensive forest tracts to the east and south. Likewise, the surroundings of Quinto Piso, Yalare and Concepción have either been legally or illegally logged and turned into monoculture crops and grasslands. At a broader scale, northwest Ecuador has the highest deforestation rate in the country, with over 25,400 ha lost annually, while the province of Esmeraldas has the highest deforestation rate in the region $(12,485$ ha/year; MAE, 2012). Habitat loss rates are also among the largest in the Neotropics (Aide et al., 2013). Additionally, coverage by national protected areas is dramatically low. Roughly, 73-98\% of the area covered by ecosystems where X. minlosi occurs is not protected according to Cuesta et al. (2015). Based on deforestation rates, very low protection, and the species preference for forested habitats, we suggest a revision of its conservation status in Ecuador, where it might rank as Endangered following the International Union for Conservation of Nature (IUCN) guidelines for regional assessments (IUCN, 2003). Although its status in Colombia is less severe, a more thorough conservation assessment of its global population is also suggested, taking into account future deforestation and climate change scenarios (Bird et al., 2011).

The scanty basic natural history data available to date either suggest that $X$. minlosi occurs in low densities or that its elusive behaviour precludes obtaining behavioural and ecological information. Further field studies might demonstrate that its putative rarity is related to specific habitat requirements, small clutch size, low recruitment, or high predation rates, and that populations are experiencing a serious decline. Further, its taxonomic status needs study since the Ecuadorian population (currently assigned to the Colombian subspecies X. m. umbraticus, which apparently does not range south to the Colombia-Ecuador boundary) might represent an undescribed, geographically isolated taxon (Ridgely \& Greenfield 2001).Texto...

\section{ACKNOWLEDGEMENTS}

Thanks to Roger Ahlman for sharing field observation and to two anonymous referees for their critical revisions. AS-U thanks A. Arcos T. for continuous support, and Fundación Imaymana, Neblina Forest and Mamba Negra for facilitating his field work. JF thanks the Mashpi community for their hospitality and friendship, Fernando Espíndola for help with distribution models, and Mary Imba for her permanent support.

\section{REFERENCIAS}

Aide, T.M., Clark, M.L., Grau, H.R., López-Carr, D., Levy, M.A., Redo, D., Bonilla-Moheno, M., Riner, G., Andrade-Núñez, M.J. \& Muñiz, M. (2013). Deforestation and reforestation of Latin America and the Caribbean (2000-2010). Biotropica, 45, 262-271. doi: http://doi.org/10.1111/j.1744-7429.2012.00908.x

Bird, J.P., Buchanan, G.M., Lees, A.C., Clay, R.P., Develey, P.F., Yépez, I. \& Butchart, S.H.M. (2011). Integrating spatial explicit habitat projections into extinction risk assessments: a reassessment of Amazonian avifauna incorporating projected deforestation. Diversity and Distributions, 2011, 1-9. doi: http://doi.org/10.1111/j.1472-4642.2011.00843.x

BirdLife International. (2016, December 12). Species factsheet: Xenerpestes minlosi. BirdLife International. URL: http://www.birdlife.org.

Cuesta, F., Peralvo, M., Baquero, F., Bustamante, M., Merino-Viteri, A., Muriel, P., Freile, J. \& Torres, O. (2015). Áreas prioritarias para la conservación de la biodiversidad en el Ecuador continental. Quito: Ministerio del Ambiente, Condesan, Pontificia Universidad Católica del Ecuador and GIZ.

Derryberry, E.P., Claramunt, S., Derryberry, G., Chesser, R.T., Cracraft, J., Aleixo, A., Pérez-Emán, J., Remsen, J.V.\& Brumfield, R.T. (2011). Lineage diversification and morphological evolution in a large-scale 
continental radiation: the Neotropical ovenbirds and woodcreepers (Aves: Furnariidae). Evolution, 65, 29732986. doi: http://doi.org/10.1111/j.1558-5646.2011.01374.x

Durán-Quesada, A.M., Reboita, M. \& Gimeno, L. (2012). Precipitation in tropical America and the associated sources of moisture: a short review. Hydrological Sciences Journal 57: 612-624. doi:

http://doi.org/10.1080/02626667.2012.673723

Gelis, R. A. (2014, Octubre 8). eBird checklist S20202924. eBird: An online database of bird distribution and abundance. Ithaca, New York. URL: http://ebird.org/ebird/view/checklist/S20202924

Greeney, H.F. \& Nunnery, T. (2006). Notes on the breeding of northwestern Ecuadorian birds. Bulletin of the British Ornithologists Club, 126(1), 38-45. URL:

http://www.biodiversitylibrary.org/item/127064\#page/40/mode/1up

Guerrero, M. (2002). Colagris Alibandeado, Xenerpestes minlosi. En T. Granizo, C. Pacheco, M.B.

Rivadeneira, M. Guerrero \& L. Suárez (Eds.), Libro rojo de las aves del Ecuador (pp. 277). Quito: Simbioe, Conservación Internacional, EcoCiencia, Ministerio del Ambiente and UICN.

Hilty, S.L. \& Brown, W.L. (1986). A guide to the birds of Colombia. Princeton: Princeton University Press.

IUCN (2003). Guidelines for application of IUCN red list criteria at regional levels, version 3.0. IUCN Species Survival Commision. International Union for Conservation of Nature, Gland, Switzerland. URL: http://www.iucnredlist.org/technical-documents/categories-and-criteria

Jahn, O. (2011). Bird communities of the Ecuadorian Chocó: a case study in conservation. Bonner Zoologische Monographien, 56, 1-514. URL: http://www.zobodat.at/pdf/Bonner-ZoologischeMonographien 56 0001-0514.pdf

Ministerio del Ambiente del Ecuador-MAE. (2012). Línea base de deforestación del Ecuador continental. Quito: Ministerio del Ambiente.

Phillips, S.J., Anderson, R.P. \& Schapire, R.E. (2006). Maximum entropy modeling of species geographic distributions. Ecological Modeling, 190, 231-259.

Remsen, J.V. (2003). Family Furnariidae. En J. del Hoyo, A. Elliott \& D. Christie (Eds.), Handbook of the Birds of the World, vol. 8: broadbills to tapaculos (pp. 162-357). Barcelona: Lynx Edicions.

Remsen, J.V. (2016, August 23). Double-banded Greytail (Xenerpestes minlosi). En J. del Hoyo, A. Elliott, J. Sargatal, D.A. Christie \& E. de Juana. (Eds.), Handbook of the Birds of the World Alive. Barcelona: Lynx Edicions. URL: http://www.hbw.com/node/56522

Ridgely, R.S. \& Gwynne, J.A. (1989). A guide to the birds of Panama. Princeton: Princeton University Press.

Ridgely, R.S. \& Greenfield, P.J. (2001). The birds of Ecuador. Ithaca: Cornell University Press.

Ridgely, R.S. \& Greenfield, P.J. (2006). Aves del Ecuador. Quito, Ecuador: Academia de Ciencias de Philadelphia and Fundación Jocotoco.

Solano-Ugalde, A., Arcos-Torres, A. \& Greeney, H.F. (2007). Additional breeding records for selected avian species in northwest Ecuador. Boletín Sociedad Antioqueña de Ornitología, 16(1), 17-25.

Stattersfield, A.J., Crosby, M.J., Long, A.J. \& Wege, D.C. (1998). Endemic Bird Areas of the world: priorities for biodiversity conservation. Cambridge, UK: BirdLife International.

Thomas, B. T. (1983). The Plain-fronted Thornbird: nest construction, material choice, and nest defense behaviour. Wilson Bulletin, 95, 106-117. URL: https://sora.unm.edu/node/130005 
Whitney, B.M., Pacheco, J.F., da Fonseca, P.S.M. \& Barth, R.H. (1996). The nest and nesting ecology of Acrobatornis fonsecai (Furnariidae), with implications for intrafamilial relationships. Wilson Bulletin, 108, 434-448. URL: https://sora.unm.edu/sites/default/files/journals/wilson/v108n03/p0434-p0448.pdf

Zyskowski, K. \& Prum, R.O. (1999). Phylogenetic analysis of the nest architecture of Neotropical ovenbirds (Furnariidae). Auk, 116, 891-911. URL: https://sora.unm.edu/node/26128 